\title{
WOMEN AND THE GUITAR IN SPAIN'S UPPER CLASSES ${ }^{1}$
}

\author{
Richard PINNELL
}

\begin{abstract}
The 13th-century Libro de Apolonio featured women and an aristocratic guitar called the vihuela. This instrument's prestige continued into the 16th century in the hands of empresses, queens, princesses, and ladies of the Spanish upper classes. Their inclination to perform on the fretted instruments enhanced the impact of humanistic and educational values emanating from the Italian Renaissance into Spain's Mediterranean ports.

On the return ships, starting around 1550, Spanish women launched the baroque guitar's expatriation at Naples, which gathered forces for a northward invasion through the city-states and into the rest of Europe as the guitarra española. Reinforcements came from Spanish and Italian popular culture, as it advanced north to Scandinavia and west to the Americas. Following in the footsteps of the Habsburg infantas who became the wives of Louis XIII and Louis XIV of France, the guitar movement reached its apotheosis under Bourbon rule, which after 1700 circled back into Spain. From 1660 to 1800 the princesses and queens of the Habsburg, Savoyard, Stuart, and Bourbon dynasties, continually elevated the instrument's prestige, adding to its popularity and opening the way for its influence in secular art music.
\end{abstract}

\section{Resumen}

El tema del Libro de Apolonio, del siglo xilI, se basa en las mujeres y una aristocrática guitarra llamada vihuela. El prestigio de este instrumento continuó durante el siglo XVI en manos de emperatrices, reinas, princesas y señoras de las clases altas españolas. Su inclinación a tocar este tipo de instrumentos expandió la importancia de los valores humanísticos y educativos procedentes del Renacimiento Italiano que llegaban a los puertos mediterráneos de España.

En los barcos de regreso, empezando alrededor de 1550, las mujeres españolas iniciaron la expatriación de la guitarra barroca a Nápoles, cuyas fuerzas estaban preparadas para una invasión del Norte a través de las ciudades-estado y en el resto de Europa como la «guitarra española». Los refuerzos vinieron de la cultura popular italiana y española, avanzando tanto hacia el Norte a Escandinavia como al Oeste a América. Siguiendo los pasos de las infantas Habsburgo, que se convirtieron en las esposas de Luis XIII y Luis XIV de Francia, el movimiento de la guitarra alcanzó su apoteosis bajo los Borbones, los cuales, después del 1700, regresaron a España. Desde 1660 a 1800, las princesas y reinas de las dinastías de los Habsburgo, Saboya, Estuardo y Borbones, elevaron continuamente el prestigio de este instrumento, añadiendo más popularidad y abriendo el camino para su influencia en la música artística secular.

The history of women and the guitar lasted at least five centuries in Spain. Their attachment to it dates back to medieval times, because certain princesses are already playing the vihuela in the Libro de Apolonio. Although this was a fictional tale written in Spanish during the 13th

1. I am indebted to the Program for Cultural Cooperation between Spain's Ministry of Culture and United States' Universities for advancing the present research. The Program awarded a stipend for travel that enabled me to consult unique library sources. 
century, ${ }^{2}$ the Libro portrays actual performance practices and the social position of the preferred instrument. The vihuela is the only instrument in the story; all three protagonists play it. ${ }^{3}$ Apolonio, King of Tyre, is a fine performer: "Neither Apollo nor Orpheus can match him on the vihuela," and the King shares this ability with the Princesses named Tarsiana and Luciana. Luciana's music, in fact, is her main attraction (verse 179):

Faziá fermosos sones,
fermosas deballadas,
Quedaba a sabiendas
la voz a las vegadas;
Faziá a la vihuela
dezir puntos ortados,
Semejaban que eran
palabras afirmadas.
Los altos e los baxos,
todos d'ella dizién:
_ ‘La dueña e la vihuela
tan bien se avienén!”

She was making pretty sounds, many pretty concerts,

When all became aware, as rumored to the outskirts;

She made her vihuela speak celestial chords,

Transforming them into veritable words.

The people high and low, all spoke of her by saying,

- "The mistress and her vihuela: they are so becoming!"

It is notable that Luciana plays chords. ${ }^{4}$ Apolonio is duly impressed with her music and eventually marries Luciana, yet her presence fades with the arrival of her daughter Tarsiana, who also becomes a musician.

According to the Libro de Apolonio, Tarsiana was trained in her youth. From age seven to fifteen, having been abandoned by her parents, she received a thorough education that included musical subjects (v. 350):

$$
\begin{gathered}
\text { Cuando fue de siet' años, } \\
\text { diéronla al escuela; } \\
\text { Apriso bien gramátiga } \\
\text { e bien tocar vihuela... }
\end{gathered}
$$

\author{
When she was age seven \\ they took her to school; \\ She quickly learned grammar \\ and mastered the vihuela...
}

2. See Libro de Apolonio, ed. Manuel Alvar (Barcelona: Planeta, 1984). Although the Libro was based on an earlier Latin text, the anonymous Spanish author enlarged the story with Iberian elements. In the episodes cited below, the English translations are my own.

3. The vihuela or viola that is so prominent in the Libro de Apolonio appeared in other 13th-century literature and iconographical sources as one of the early configurations of the guitar.

4. The implication here is that the romances sung by the protagonists were accompanied with strummed chords (at a time when music was generally considered to be monophonic or perhaps heterophonic). Juan Bermudo confirmed the use of the chordal texture along with an old tuning: "El temple de la guitarra a los viejos no difiere de ésta a los nuevos: sino que la quarta cuerda suelen abajar un tono... Este temple más es para romances viejos, y música golpeada: que para música del tiempo." See Declaración de instrumentos musicales, Osuna: 1555, facs. ed. M. Santiago Kastner (Kassel: Bärenreiter, 1957), fol. $28 \mathrm{v}$. If the medieval romances were strummed, they were inevitably chordal. A homophonic accompaniment was the result, and may thus have been of Spanish origin, inasmuch as both this texture and the romance followed the guitar's trajectory through Naples into Lombardy, the birthplace of monody and early opera. 


\author{
Amábala el pueblo \\ de Tarso la cibdat... \\ Dízenle Tarsiana, \\ ésta era verdat.
}

\author{
She was loved by everyone \\ in the city of Tarsus... \\ They called her Tarsiana, \\ for such was the truth.
}

The Libro explained further that Tarsiana had been playing the vihuela for some time when she became a juglaresa, the equivalent of the jougleresse in Provence, a working woman devoted to a musical career. As Tarsiana matured with the need of supporting herself, she gained fame for her music, drawing ever more attention and pay for her ability (v. 426):
Luego el otro día, de buena madurgada,
Levantóse la dueña ricamient' adobada,
Priso una viola, buena e bien temprada,
$E$ salio al mercado violar por soldada...
Cuando con su viola hobo bien solazado,
A sabor de los pueblos hobo asaz cantado,
Tornóles a rezar un romanz bien rimado
De la su razón misma por ó habiá pasado.

Later the next day, quite early in the morning,

The lady arose, adorned with fine clothing,

She took up a vihuela of value and fine tuning,

And went off to market all her best playing...

When with her vihuela she became accustomed

To the taste of the people of what had been sung,

She returned to recite a well rhymed romance

That she had invented on what had been done.

There was a real Tarsiana, who must have inspired this story, but she was only the model juglaresa. By then other women were also travelling as performers and making a living with the vihuela. ${ }^{5}$ The case of Tarsiana was nevertheless the exception rather than the rule, because working-class women seldom received recognition that would enable us to study their lives. Women's services were documented in the royal treasury books, including payment for their performances, but further details about them are lacking. A certain "Graciosa", for example, served the queens of Aragon and Navarre for the decade between 1409 and $1419 .{ }^{6}$ An investigation into the activities of such professional musicians and musical servants would be timely, but for the paucity of personal data, we must turn to the lives of the royalty for more information.

5. Ismael FERNÁNDEZ DE la CUESTA, Historia de la música española, 1: Desde los orígenes hasta el "ars nova" (Madrid: Alianza Editorial, 1983), p. 348ff.

6. Maricarmen GOMEZ, "Some Precursors of the Spanish Lute School," Early Music XX (1992), p. 590. 


\section{The Vihuela in the Siglo de Oro}

La vihuela: "Instrumento favorito de nuestras reinas."7

Fortunately the princesses and queens who played the guitar-like instruments left a paper trail of activities, a plethora of biographical details that linger in the state papers, chronicles, and wills of the Golden Age. While women across Europe were adopting the lute, Spanish queens preferred the vihuela the aristocrat of guitar-like instruments.

The early guitar types had the familiar hourglass shape and a flat or nearly flat back, but, just as today, they came in several configurations. There were large, mid-sized, and small instruments strung in several ways, and they appeared repeatedly in Spanish iconographical sources and medieval literature. The guitarra latina, by name a vestige of the Roman Empire, must have descended from the Roman cithara. Yet there were other guitar-like instruments in use, such as Tarsiana's vihuela. These instruments were so popular in Spain that they even eclipsed the fame of the lute when it was becoming the leading instrument in the rest of Europe.

The lute, called the guitarra morisca at the court of Alfonso the Wise and in the "Cantigas de Santa Maria" which he sponsored, had a long history in Spain, but its future would forever remain under the daunting shadow of Islam. The lute was known already in ancient Greece and Rome, but ironically the Moorish invasion that reinforced the lute's position across Europe, also hindered that instrument's acceptance where the invasion had been most effective and enduring. Men could choose to perform on any instrument; indeed, the minstrels often played the lute at the Peninsular courts, but the women who played it represented an exclusive group. Throughout the Middle Ages it was the instrument of Arabian slave girls who immigrated to the Peninsula as singers and dancers. ${ }^{8}$ Some even performed at court. The lute was therefore inappropriate for female royalty. The princess and queen had to choose from the "received" instruments, and since the lyre and kithara were no longer available, they chose the vihuela. Besides, the vihuela was the equivalent of the vielle, the preferred instrument of the trobairitz. Princess Isabella of Occitania, for instance, played the vielle, according to her vida. ${ }^{9}$ The Libro de Apolonio suggests, therefore, that in the 13th century the vihuela had already gained prestige among women of the aristocracy. It was clearly their instrument.

Johannes Tinctoris travelled to the Peninsula at the end of the 15 th century and noted the proliferation of stringed instruments. His travels there were facilitated by his service in Naples,

7. Higinio ANGLÉs, La música en la Corte de Carlos V, con la transcripción del "Libro de Cifra Nueva para tecla, harpa y vihuela" de Luys Venegas de Henestrosa... Barcelona: Consejo Superior de Investigaciones Científicas (reprint by CNRS, 1965), vol. I, p. 57.

8. Julián Ribera, Music in Ancient Arabia and Spain, Being la Música de las Cantigas, trans. and ed. Eleanor Hague and Marion Leffingwell (Stanford: Stanford University, 1929; reprinted at New York: Da Capo Press, 1970), Chapter $\mathrm{X}$.

9. Meg Bogin, The Women Troubadours (New York \& London: Paddington Press, 1976), p. 173. 
both a Spanish court and an international port that served as the inlet of Spanish commerce from Valencia and Barcelona, the cities Tinctoris visited. Tinctoris wrote of his Catalonian travels and experiences in his last treatise, the one completed around 1487. In Book IV he described the instruments he had seen on his trip. Among them were the lyra, viola, and ghiterra (the lute, large guitar, and small guitar). After specifying their stringing in courses or pairs of strings, he addressed the music and performers he had seen in these and other travels. Tinctoris highlighted some of the instruments: the plucked viola (the gut-strung viola da mano or vihuela de mano) was generally the one most often used, yet the ghiterra was the female favorite:

The lyra is described as having seven strings... The strings are generally of ram's gut... The lyra is often called 'testudo' by the poets, as we have already remarked, by reason of its [tortoise-like] shape... but it is now known everywhere as the lute, perhaps to distinguish it from the various other instruments... that, for example, invented by the Spanish, which both they and the Italians call the viola. This viola... is flat and, in most cases, curved inwards on each side...

While some play every sort of composition most delightfully on the lute, in Italy and Spain the viola without a bow is more often used... Nor must I pass over a recent event, the performance of two Flemings, the brothers Charles and Jean Orbus, who are no less learned in letters than skilled in music. At Bruges, I heard Charles take the treble and Jean the tenor in many songs, playing this kind of viola so expertly and with such charm that the viola has never pleased me so well...

The ghiterra is used most rarely, because of the thinness of its sound. When I heard it in Catalonia, it was being used much more often by women, to accompany love songs, than by men. ${ }^{10}$

Of all the instruments in the Tinctoris travelogue, it was the vihuela that captured the spotlight in the 16th century. It became Spain's largest and finest guitar. So many women in high places had followed Tarsiana's example, it seems, that the vihuela became the century's foremost vehicle for art music and courtly entertainment.

Stringed instruments were valuable possessions in the 16th century. Their value had to be reported in wills and inventories of the upper class. When an aristocrat died it was customary to take inventory of personal effects in order to make a proper disposition of the estate, for an inventory always helped to dissolve disputes over willed property. If items in the estate included a musical instrument, then it may have been for personal use. The property of the Duke of Calabria, Viceroy of Valencia, for instance, included two fine vihuelas and two lutes at the time of his death. ${ }^{11}$ Why would he own such instruments, if not to loan them to virtuosi in his presence and to perform on them as an amateur? Likewise, posthumous inventories of ladies indicated that women

10. Anthony BAINES, trans. and ed., "Fifteenth-century Instruments in Tinctoris's De Inventione et Usu Musicae," Galpin Society Journal III (1950), p. 22ff. p. 187.

11. [Anon.] "Inventario de los efectos del Duque de Calabria," Revista de Archivos, Bibliotecas y Museos I (1871), 
also owned stringed instruments. In Table 1, data extracted from references already published by Antonio Corona, ${ }^{12}$ ladies of influence owned vihuelas in each generation of the century:

\section{Table 1 Vihuelas Belonging to Spanish Ladies in the 16th Century}

Queen Juana of Castile, daughter of Isabella I and mother of Charles V

Empress Isabel, consort of Charles V, Holy Roman Emperor $=$ Charles I of Spain

Princess Juana of Austria, daughter of Charles V and Isabel of Portugal

Elizabet Farrera y Albans Balle, a lady of Barcelona

(Note: $\mathrm{d}=$ ducats, $\mathrm{r}=$ reals)
The inventory compiled in 1545 mentions a box containing pearls and a small vihuela.

"[One large vihuela with one rose, valued at $3 \mathrm{~d}$. One medium-sized vihuela... valued at $5 \mathrm{~d}$. Another vihuela, smaller than the aforementioned, valued at $3.5 \mathrm{~d}$.]" 1539

"[A vihuela, the back made of alternating strips of Brazil and white wood and the sides of ebony... $8 \mathrm{r}$.]"

"[Item: on the table behind the corridor there are three viols, one of 9 strings and the other two are: one of 11 strings and the other bowed.]" 1591

Women of the 16th-century court not only owned vihuelas and heard them in musical spectacles as well as in their private chambers, they also played them. Members of the royalty even received vihuela instruction from musicians in their service.

As implied in Table 1, Juana of Castile (1479-1555), the daughter of Ferdinand and Isabella, was a vihuelist. Juana became titular Queen of Spain on the death of her mother, but intolerance of her husband's love affairs earned the infamy that kept Juana from assuming her own reign. She married Philip the Fair in 1496, and the two came to share their inheritances: she first became Archduchess of Flanders; he would soon become King of Castile. It was there that the Spanish people gave to her her nickname: Juana la Loca, loca de amor [Joanna the Mad, crazy for love]. The nickname came as a result of Juana's uncommon devotion to her husband. To be sure there was one situation that always provoked her passionate outburst — her husband's infi-

12. Antonio Corona AlCAlde, "The Viola da Mano and the Vihuela, Evidence and Suggestions about Their Construction," The Lute (London) XXIV (1984), 3-32. Brackets [] indicate my translation of the quoted material. 
delity. On one occasion in 1504 , for instance, as she was returning to their Flemish court after a trip to Spain, she discovered Philip at home with a courtesan in her place. Incensed, Juana scratched her face and cut off her hair $!^{13}$ This was uncalled for, a rash response from the perspective of the libertine lifestyle of aristocrats with its double moral standard. From then on, Fair Philip would have reason to hide all of his actions, whether personal affairs or matters of state, from her, especially inasmuch as it was she who had just inherited the throne of Castile, not he. There was too much at stake to treat her as sane.

Juana and Philip became the co-rulers of Castile on the death of her mother Isabella the Catholic. In 1506 they went to Spain in order to accept their titles. The widower Ferdinand still ruled Aragon and offered to act as the chief administrator over their domain. Juana's unpredictable behavior remained a concern, however, giving Ferdinand a pretense for leaving Juana in the wings during her own rule. He also avoided intervening on her behalf when her husband took over, and although Philip died within a year of their accession, Ferdinand chose to leave Juana in continuous confinement because of a provision of Isabella's will. It entitled Juana's relatives to rule in her stead, if she were somehow left incompetent.

In her youth Juana received exposure to the plucked strings in a musical court, where minstrels proliferated and where she must have received musical training. Whether by exposure, training, or both she chose the vihuela as her own. Likewise her sister Catalina, Henry VIII's first wife, had a similar musical allegiance; the several "Spanish vialles" in the royal instrument collection must have been for her amusement. Once Juana's confinements began, she turned to her music for solace. In doing so, she acted independently of Baldassare Castiglione's influential book entitled Il cortegiano (1528), that prescribed performance on her preferred instrument as the epitome of refined taste. ${ }^{14}$ Juana habitually sang and played the vihuela, although she owned several other instruments. Having acquired some for her pastime, she also kept a retinue of fine Flemish and Spanish musicians to deliver performances and to give her more instruction. At least two of her musicians played the guitar. A certain Alonze le Gysternier - the guitarist - was paid for his services to the household in 1506, with the implication that he had been brought from Flanders. ${ }^{15}$ Martín Sánchez, a Spanish vihuelist, served her for three decades during her confinement at the castle of Tordesillas:

At Tordesillas a strict regime patterned after convent life was installed by an overseer appointed by Ferdinand, who was given permission to beat her "if necessary for her health" (i.e., if she refused to eat)... A tañedor de vihuela, Martín Sánchez, is listed in the Queen's service in 1517, passing to her daughter's employ between 1522 until her marria-

13. Petrus Martyr de Angleria, Opus epistolarum: Liber decimus septimus. Alcalá: 1504, p. CCLXXI (see facs. reprint in Opera..., ed. Erich Woldan, Graz: Akademishe Druck- u. Verlagsanstalt, 1966).

14. "Il cantare alla viola is much better, because all the sweetness consisteth in one alone." See Oliver Strunk, ed., Source Readings in Music History (New York: Norton, 1959), p. 284.

15. Mary Kay Duggan, "Queen Joanna and Her Musicians," Musica Disciplina XXX (1976), p. 80. 
ge in 1525 , when he returned to Joanna's household. His name remained on the Queen's rolls until $1543 .{ }^{16}$

Juana finally died in 1555 after nearly forty years of confinement.

Juana helped to reveal the gift of music in her children. As a young parent in Flanders she obtained instruction for them that would expose and develop their talents. In their youth they studied performance with private tutors. Prince Charles and his sisters, Eléonore, Marie, and Isabelle, were trained on both the keyboard and the fingerboard: their instruments were the clavichord, vihuela, and lute. In 1512 they were taking lessons with Henry Bredemers on the "grandes violes." 17 While it is possible that these lessons were on the viola da gamba, it is more likely that Juana would see to their training on her own instrument. The vihuela grande was then Spain's most imposing instrument: it was the tour de force for a journeyman luthier's examination. ${ }^{18}$ Fortunately the lone surviving vihuela, that displayed in the Musée Jacquemart in Paris, is an ornate vihuela grande with the string length of a modern guitarra de concierto. Moreover, Prince Charles and his sisters also played other plucked strings. In 1514 they were studying the lute with Bredemers. ${ }^{19}$ The lute remained the personal favorite of Eléonore and Marie, while Juana's last surviving daughter, Catherine, became an ardent vihuelist.

"Catalina," as she was called, was born in 1507; as Juana's youngest child, she was also born in Spain. Records of the royal treasury contain repeated payments to her mother's vihuelist, Martín Sánchez (as cited above). He worked for Juana, but the titular queen also released him temporarily to serve her daughter Catherine. As the princess matured, Sánchez went on loan to her as "[player of the vihuela who serves the aforementioned Princess Catherine]," according to records in the Archive of Simancas. ${ }^{20}$ Sánchez was Catherine's chamber musician and vihuela instructor for three years. The vihuelist returned to Juana's service in 1525, when the princess married. Catherine's marriage took her to Portugal, where she became Queen-consort of John III, who ruled from 1521 to 1557 . This monarch was none other than the famed patron of Luis Milán's El Maestro, published in 1536, the first of the seven great vihuela books. Catherine's presence in Portugal explains why this foreign king, at that a famous warrior, suddenly left a substantial pension for a vihuelist on the other side of Spain! Perhaps Catherine had known Milán in Valencia, for he was not a traveller, but, no matter, on his reputation alone he would have merited a stipend from their court to publish a book for her amusement. Luis Milán was not only a great vihuelist but also a well-rounded caballero in the service of Germaine de Foix.

Juana's eldest son, Charles of Ghent, came to rule in her stead as heir to both the Spanish monarchy and the Austrian Empire. Prince Charles and the royal siblings favored the vocal

16. Ibid., p. 89.

17. Edmond Vander Straeten, La Musique aux Pays-Bas. Documents inédits et annotées..., 8 vols. (Brussels: C. Muquardt, 1867-1888) vol. VII, p. 202.

18. José SUBIRÁ, Historia de la música española e hispanoamericana (Barcelona: Salvat, 1953), p. 202.

19. VANDER STRAETEN, loc. cit.

20. ANGLÉs, op. cit., vol. I, p. 21. 
polyphony of Flanders, then at its height of perfection, at their courtly affairs and worship services. As for music in their chambers, however, Charles preferred the keyboard and the fretted instruments he could play. Once he began to rule, Charles favored the viol consort and the company of vihuelists. Ordinarily instrumental soloists went along with him on his continental campaigns. The young vihuelist Alonso Mudarra probably accompanied him to Italy in $1529 .{ }^{21}$ The next year his retinue included Ryckaert De Mont, a virtuoso guitarist who followed la mode espagnole. ${ }^{22}$

The Emperor married Isabel of Portugal, who owned three vihuelas of her own (see Table 1). Like her mother-in-law, the Empress saw to it that a musical education was part of the rearing of her children: the future Philip II (1527-1598), and the Austrian Princesses María (1528-1603) and Juana (1535-1573). As shown in a biography of Princess Juana, namesake of the titular Queen of Castile, the Princess was a student of music:

[Scrupulously educated by her mother, Doña Isabel, she made, from her early childhood, rapid progress in letters; at eight years of age (Juana) knew Latin and could play various instruments]. ${ }^{23}$

One of these was the vihuela noted in Table 1: an ornate instrument with a back of dark red and white alternating stripes and the sides of ebony. ${ }^{24}$ Music continued to interest Juana and María, the sisters of Prince Philip, because tutorial instruction in the arts was now the characteristic preparation of every princess:

[The sisters of Philip II loved and cultivated music in their home, from the time of their infancy until they left Spain. This explains why, as Doña María left for the Austrian court in 1548 and Doña Juana, for that of Portugal in 1552, that they possessed a musical culture more than sufficient to enable them to acquiesce in the artistic environment of the royal houses of Europe. Therefore, one can deduce that the sisters of Philip II -zealously educated by their mother since little children- knew how to play the clavichord, the vihuela.... ${ }^{25}$

During the reign of Charles $\mathrm{V}$, the vihuelist Luis de Narváez came into contact with the imperial household. Narváez obtained a post with the choirboys of the royal chapel, officially, but, unofficially, his proximity to the ruling family enabled him to teach vihuela music to the children and perhaps also their mother, Isabel of Portugal. ${ }^{26}$ In fact, since Isabel was herself a

21. Robert Stevenson, "Mudarra, Alonso" in The New Grove Dictionary of Music and Musicians (London: Macmillan, 1980), vol. XII, p. 757.

22. VANDER STRAETEN, op. cit., vol. II, p. 372.

23. Manuel SERRANo y SANZ, ed., Apuntes para una biblioteca de escritoras españolas, desde el año 1401 al 1833 , 2 vols. (Madrid: Revista de Archivos, Bibliotecas y Museos, 1905), vol. I, p. 76.

24. Jaime Moll, "Libros de música e instrumentos musicales de la Princesa Juana de Austria," Anuario Musical XX (1965), p. 23f.

25. ANGLÉs, op. cit., vol. I, p. 76.

26. Hopkinson SMith, "Narváez, Luys de" in The New Grove Dictionary of Music and Musicians (London: Macmillan, 1980), vol. XIII, p. 39. 
vihuelist, she may have been responsible for seeking his services in the first place. Narváez must have worked in this capacity after the publication of his vihuela book of 1538. Prince Philip continued to play the instrument, for on the occasion of his first marriage, to Maria de Portugal, he performed on the vihuela to celebrate the event. ${ }^{27}$ The Prince was maturing, meanwhile, and his father was gradually increasing his responsibilities. He became his father's ambassador, and like him, Prince Philip toured with his vihuelists in tow. He took Narváez along with him on an extended tour of the Continent and perhaps also for his honeymoon year in England, on the occasion of his second marriage, to Mary Tudor. That Prince Philip retained the services of Narváez in his travels, helps to confirm the fact that he had probably been his student.

There is circumstantial evidence that Philip II's sisters, Juana and María, continued further study of the vihuela under Alonso Mudarra. In 1546 the Princesses went to La Casa del Infantado or the Princely Palace of Guadalajara. Mudarra had been serving as vihuelist at the Palace ever since his youth, under the patronage of Duchess María Pimentel. ${ }^{28}$ The year 1546 marked not only the publication of Mudarra's vihuela book but also the year that the Princesses spent at this residence. That Palace remained a typical rendezvous of the royalty: in 1557 it was the place of retirement for Eléonore of Austria, upon the death of her second husband, Francis I of France, and in 1560 Philip II and Isabel de Valois, his third wife, were married there. ${ }^{29}$ Diego Pisador, in the meantime, had dedicated the publication of his only vihuela book to Philip II in 1552.

Philip's sisters found connections to other courts by the usual contrived marriages. Juana followed her aunt Catherine to Lisbon as an aristocratic vihuelist and married Prince João Manoel of Portugal in 1552, though he died only two years later, and thus never replaced his father on the throne. The dowager princess returned home, where she assisted the Habsburg rule by acting as the part-time regent of Spain. A devout Catholic, Juana founded the famous Descalzas Reales convent in Madrid. It was there that she gave herself to pious exercises and to the performance of more instrumental music. ${ }^{30}$

Her sister María married Prince Maximilian of Austria, who ascended the ranks by becoming King of Bohemia, then Hungary. Finally in 1564, he assumed the throne of the Habsburg Empire as Maximilian II. His education in Spain must have prepared his leanings as a patron of the arts, in which he may have supported some musicians. Thus the descendants of Charles $\mathrm{V}$ and Isabel of Portugal took their preferences abroad and undoubtedly their instruments, which enhanced the guitar's acceptance far to the east and west. Since many who performed on the aristocratic guitar were part of the royal household, it is possible to review their relationships with a family tree:

27. Emilio Pujol, ed., Alonso Mudarra, Tres libros de música en cifra para vihuela (Sevilla, 1546), transcripción y estudio (reprint, Barcelona: CNRS, 1984), p. 13.

28. Ibid., p. 31 .

29. Santiago NadAL, Las cuatro mujeres de Felipe II (Barcelona: Ediciones Mercedes, 1944), p. 118.

30. SERRANo, op. cit., vol. I, p. 78. 
Table 2 Royal ViHUELISTS*

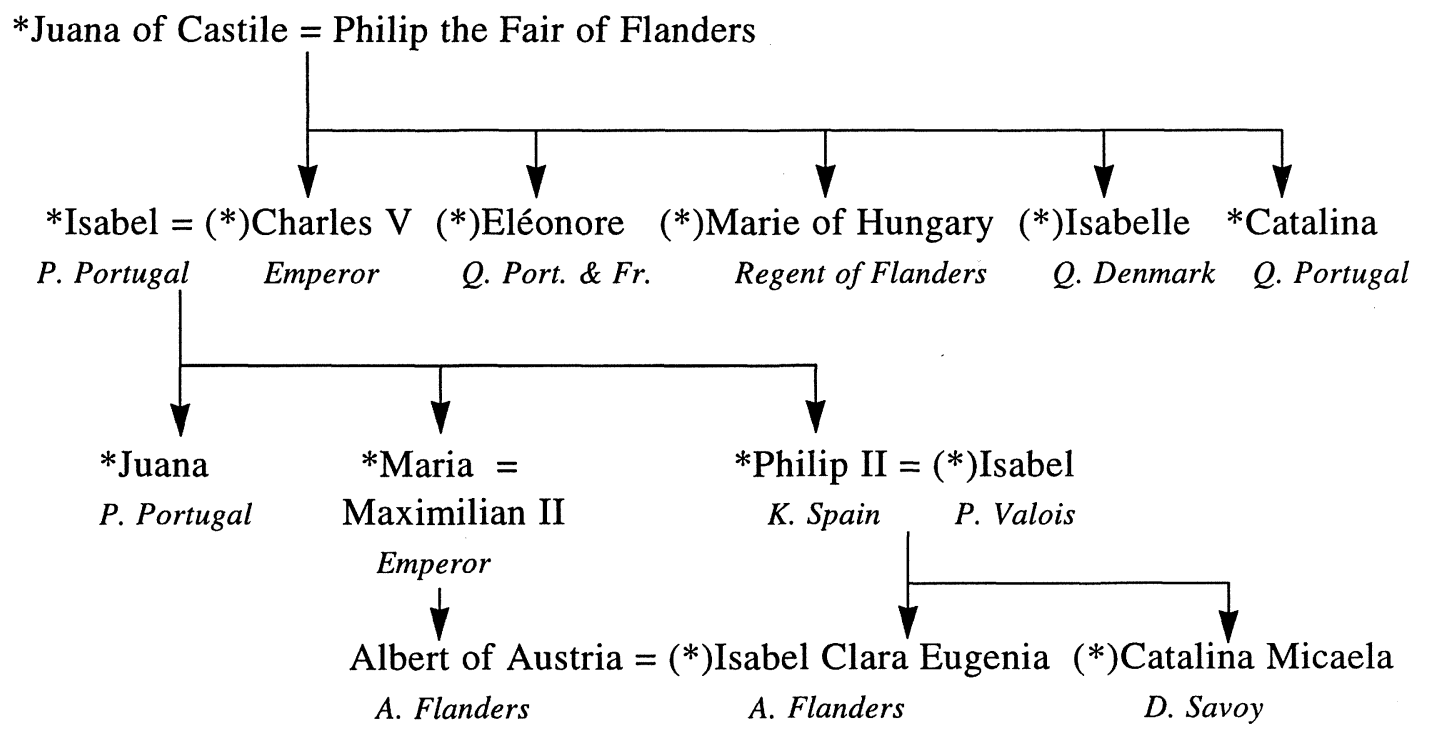

\section{Notes:}

* is a vihuelist; $\left(^{*}\right)$ probably a vihuelist.

Emperor means Holy Roman Emperor of the Habsburg dynasty.

$P$. is for Princess of, $K$. is for King of; $A$. is for Archduke of or Archduchess of, etc.

Not all the posterity appears, of course, only that relevant to the present discussion.

Queen Isabel de Valois patronized the services of the blind Miguel de Fuenllana, who published the longest and arguably the best of the vihuela books. ${ }^{31}$ One of her daughters, Isabel Clara Eugenia, followed in her footsteps as a musical patroness when she became the Archduchess of Flanders. The other, Catalina Micaela probably introduced the vihuela to Savoy, the guitar's bastion on the Italo-French Riviera during the Baroque era. As summarized in the family tree, then, there were at least several princesses, queens, and empresses, among the leading ladies of the 16th century who played the vihuela de mano. The vihuela was therefore indeed the principal instrument of the Spanish queens. No wonder there was such an outpouring of interest in the instrument during their century. 


\section{Women and the Baroque Guitar's Diffusion}

Precursors of the five-course baroque guitar began to emerge around 1550. At that time there were about as many guitar types in Spain as there were lute types in the rest of Europe. Amidst all the Renaissance guitar types, however, two formed the musical mainstream: the guitarra and the vihuela. Bermudo compared and contrasted them in 1555 . He noted their similar shape and identical characteristics: "[The guitarra is nothing more than a vihuela with the sixth and the first (strings) removed.]"32 The instruments contrasted, however, in terms of their size and audience. The guitarra was a small instrument of four courses with popular appeal. The vihuela was the larger, being an instrument of six courses, and it served both the aristocracy and musicians of the academy. Strumming was the plebeian technique for the guitarra, while refined plucking was appropriate for the vihuela. Bermudo also noted some five-course guitars in the midst of this milieu. One of these won popularity because of its utility: it combined the best of both its predecessors as it began to replace them. The first book devoted to the new guitar was published in 1596, and its author, Dr. Joan Carles Amat, named the instrument once and for all in the book's title: La guitarra española. The so-called Spanish guitar had five courses of strings, it was of intermediate size, and it admitted both former techniques, for it appealed to every class.

The democratic guitarra española might have remained a uniquely Spanish phenomenon, were it not for the women of Naples. Their romance ballads accompanied on the guitar became quite popular. The romance, since Tarsiana, at least, had been the verse form of the old narrative ballad: any number of quatrains set in octosyllabic lines told the story. Like the repertoire of the troubadours and other aristocratic singers, the Neapolitan songs dating back to 1550 with lyrics alone far outnumbered those with musical notation. However, some few circulated with notated melodic lines or with chord symbols for the guitar (letters of the alphabet) written over the lyrics, thus anticipating the concept of figured bass and the popular notation of today. The Duchess of Traetta was the patroness whose support helped to produce the first dated manuscript of romances with alfabeto. ${ }^{33}$ Her song book was entitled,

Libro de cartas y romançes españoles. Del' Ilustrissima Señora Duchessa di Traetta, mi señora que Dios guarde mil años, 1599. [Book of letters and Spanish romances of the illustrious lady, my lady Duchess of Traetta; may God keep her a thousand years, 1599].

After the Duchess of Traetta, alfabeto became the instrument's standard chordal notation for another century.

Naples remained the guitar's foothold in Italy. The city served not only as the fountainhead of the emerging popular style but also the source of performers who could deliver it. As

32. "No es otra cosa la guitarra sino una vihuela quitada la sexta y la prima." See BERMUdo, op. cit., fol. $28 \mathrm{v}$.

33. John H. BARON, "Secular Spanish Solo Song in Non-Spanish Sources, 1599-1640," Journal of the American Musicological Society, XXX (1977), p. 24. 
Spanish songs began to flourish in Naples, the guitar did likewise, for it became marketable in the hands of the Neapolitan virtuosa. Of the many performers there, the best known was "La bell' Adriana," a harpist and guitarist who accompanied her exquisite voice in solo performances across Italy. Naples thus came to be key in the supply and demand for guitar music starting around 1550. The guitar became so popular that it influenced the development of monody and the homophonic texture at Florence, where the recitativo, whether on stage or in the chamber, admitted and sometimes specified a guitar. At Mantua, Duke Vincenzo Gonzaga took the trouble of recruiting fashionable musicians from Naples for his court:

"Singers who could perform the popular Spanish secular songs to the accompaniment of a guitar, and Spanish instrumentalists, were very much in demand at Italian courts. But rather than import performers from the peninsula - a course Duke Vincenzo took only on one occasion, when he wanted Spanish actors - the court sent representatives to recruit them in the Spanish kingdom of Naples. There both native Spanish musicians and Italians of the caliber of Adriana Basile could be found....

Naples was relatively distant, and it was more convenient, as well as less costly and time-consuming, to fill routine vacancies with musicians from towns in the vicinity of Mantua. And while the Gonzagas were certainly keen to have Neapolitan virtuosi, a few of these - some vocalists from an ensemble and for solo singing, and three or four instrumentalists-were sufficient for their needs. And this quota in most instances was filled by two musician-families alone: the family of Adriana Basile and that of the Spanish guitar virtuoso Antonio Gutiérrez." ${ }^{34}$

The guitarra española, known in the present day as the baroque guitar, became the racy popular instrument of 1600 . Just as it had superseded the 16th-century guitarra and vihuela at home, it now threatened to replace the lute abroad. The guitarra española, moreover, came with strings attached. It was the medium of a musical style destined to interrupt the prima prattica, but it also became the icon of Spanish popular culture. This image was its excess baggage: the promise of adventure and excitement if not masquerades during Carnival, revels, or clandestine social encounters. By the turn of the century the five-course guitar was poised to become the most popular instrument in the rest of Europe. The new guitar served to strum those risqué dances of the New World, the dances that were either Spanish or that came through Seville (the terminal of the Columbian Exchange) en route to the rest of Europe, such as the chacona, folia, and zarabanda, along with hides, tallow, and other New World commodities that soon became necessities. The guitarist's interlude, the pasacalle, came along, too, with less important dances such as the villano and canario. ${ }^{35}$

34. Susan PARISI, "Acquiring Musicians and Instruments in the Early Baroque: Observations from Mantua," The Journal of Musicology, XIV (1996), p. 122.

35. For musical examples see Richard Hudson, The Folia, the Saraband, the Passacaglia, and the Chaconne: The Historical Evolution of Four Forms that Originated in Music for the Five-Course Spanish Guitar, 4 vols. Musicological Studies \& Documents 35 ([Rome:] American Institute of Musicology \& Hänssler-Verlag, 1982. 
What began as a plebeian style of Spain, gradually came to encompass other popular styles, and finally advanced to artistic status around 1640. The Spanish guitar flourished beyond all expectations in Italy, for once the Italians began to explore its artistic capabilities, they transformed the popular repertoire into a medium of universal appeal. They first discovered that strumming suited the interpretation of their own popular dances, but around 1640, with the lute's gradual decline, they began to incorporate the lutenist's best techniques into guitar music. Keyboard players did the same. Then the accumulated ideals and discoveries of the Renaissance spread northward along with the guitar. As the Italo-Hispanic dance style came into high demand, so also did southern European guitarists. They travelled as virtuosi and spread the good news. Gradually courtiers and their ladies began to promote the guitar in front of the lute's ever-increasing complexities. Eventually the guitarra española arrived at the major courts, scaling all social levels, as it reached the pinnacle of popularity.

\section{The Guitar in the Theatre}

Back in Spain, the dramatic tendencies and musical practices already established in the theatre of the Golden Age carried into the Baroque era without interruption along with the guitar. On the Renaissance stage Lope de Rueda had cast women as guitarists; their music spiced up the production before the advent of the theatre orchestra. Under the influence of Italian opera, theatrical music increased in importance after 1600 . Whether as a prop for the actors on stage, or behind the façade, in the wings, or as an instrument in the pit orchestra, the guitar was usually present. Guitarists had to remain on standby alert - always ready to accompany some part of the productions. The operatic tradition was beginning its trajectory out of Florence and into the rest of Europe, but the ideals of continuous music did not impact Spain until later. Instead, despite the increased length and number of actors and dancers in Spanish productions after 1600, music remained informal and incidental. The separate genres that contained guitar music were serious works, comedies, and masques, and they portrayed either mythological stories or more often, fictional yet life-like situations amidst all classes.

Playwrights depended on the guitar to accompany romance ballads alla napolitana as well as staged dances of popular culture. A romance sung to the guitar stressed popular lore or local color, and musical parts sometimes fell to women in such roles as peasant, shepherdess, or goddess. Popular dances of the day were so noisy, however, that ideally several strummers were required to supply the accompaniment!

The fact that the romance was a popular medium, however, did not hinder it as a vehicle for the expression of tender sentiments:

"Solo songs with texts in romance metre evidently were performed as strophic ballads with guitar accompaniment. The ladies who sang in the spectacle plays were gifted amateurs, more likely to sing romances in traditional style than to struggle with the intricacies of an imported foreign monodic style. Even La gloria de Niquea and El nuevo Olimpo, 
with their Italianate visual elements and versification, drew upon familiar musical traditions and Spanish antecedents for their musical scenes." 36

The guitar could help as much in the expression of pathos. Just as before, women also performed sad songs. As exemplified in a courtly spectacle that the Count of Lemos sponsored on 17 October 1617, "A peasant girl came out... carrying a guitar." Stage directions of the performance called for a romance, a ballad about a magic spell that the Moors had cast upon her people.

Lope de Vega was the outstanding dramatist who specialized in comedy. He liked to put the guitar on stage in amusing situations; his technique was, like the earlier plays, somewhat analogous to the modern situational comedy (i.e., the "sit-com"). The appearance of the guitar in his theatrical works was not always specified, but its use was obvious enough in the rendition of a plebeian romance or dance. Lope's comedy entitled El bastardo Mudarra (1612), for instance, featured a servant singing a romance to his master. Was there any need to specify which instrument Lope had in mind? The playwrights, nevertheless, often took the trouble of itemizing the guitar in their directions for the actors and of explaining how it was to be handled on the popular stage. The guitar remained in courtly productions as well. Until 1650, "The ever-present guitars were another traditional feature of musical performance on the public stages that was retained by the acting troupes when they performed at court." 37

Revelry with the guitar was precisely what Europeans had come to expect of scenes set in Spain. Such occasional scenes or settings with local color were featured in European theatrical productions and comic operas in the 18th century. The most famous were those of Pierre Augustin Caron de Beaumarchais. His plays included authentic local color. Even so, he owed his ultimate success to composers who used his plays as a basis for their operas. He wrote The Marriage of Figaro and The Barber of Seville for the theatre, yet these stories also became favorites of the operatic stage. Beaumarchais formed his concepts during a residence in Seville, so his plots were laden with lore and legend such as the Don Juan. In his Figaro, as staged by Mozart and da Ponte, women received equal billing as guitarists. To be sure, both Figaro and Cherubino, the court page, were each caught serenading their ladylove, but the Countess and Susanna, Figaro's fiancée, were also cast as guitarists! The guitar's feminine appeal was obvious to Beaumarchais, because once returned to Paris, he gave music lessons to "Mesdames," the daughters of Louis XV and his musical Queen, Marie Leszczynska.

\section{The Guitar in Spanish Life and Literature}

While Europe was discovering the guitar abroad, it was flourishing at home as the typical ornament of fictional literature, especially poetry and novels. None of the literary media had any

36. Louise K. STEIn, Songs of Mortals, Dialogues of the Gods: Music and Theatre in Seventeenth-Century Spain (Oxford: Clarendon, 1993), p. 102.

37. Ibid., p. 149 . 
break in production at 1600 , and despite a new generation of authors, they generally continued to incorporate performance practices of the guitar into their works. Writers still left images of women, characterizing them in passive and active roles. Just as in the theatre, women usually took on a passive role and allowed men to serenade them or to provide their dance accompaniments, but on occasion women also took on an active role when they played the guitar themselves for artistic satisfaction if not the rendering of their own songs and dances.

The guitar reinforced local color in the works of Cervantes and Lope de Vega. Cervantes set the mood in La casa de los celos (The House of Jealousy, c.1604), with a pair of guitarists. Lauro and Corinto serenade Clori in the pastoral scene, and soon she is singing along. Literary models witness, time and again, that women often found themselves on the receiving end of a serenade. The medieval serenade endured in Spain. An impromptu concert outside a lady's window was like giving her a bouquet of flowers, a high complement from any suitor. In Lope's $L a$ inocente Laura, as expected, Laura witnessed a typical evening song in her honor. In the Cervantine Don Quixote, Vicente de la Roca was the rogue who gradually conquered his lover's heart by singing romances under her window (Part I, Ch. 15).

By then it was every poet's practice to invoke the gods of antiquity. Spanish writers were effusive when they adopted the humanistic tradition emanating from Florence, because it resonated with that same tradition already begun in Spain as early as the Libro de Apolonio. ${ }^{38}$ When depicting Greek lore, Lope cast females as musical protagonists, but with idealized ancient instruments. In his Laurel de Apolo (1630), Laura plays the lyre; in his sonnets, Amaryllis or a servant may also play it. Real women also emerge in the Laurel de Apolo. Lope likens Ana de Ayala (episode 1), Isabel de Ribadeneyra (1), and Ana de Zuazo (8), to the muses, and María de Zayas (8) to Sappho, for their poetry and musicianship. All the poetesses of the Laurel have been identified in the literary world. ${ }^{39}$

Lope's most famous female author in the Laurel de Apolo was Juliana Morell (c.1594-1653), a remarkable femme savante and musician. She was the only child of Juan Antonio Morell, a Catalan financier, and a poor mother who died from the complications of childbirth. Juan Antonio thus centered his domestic life on Juliana and her education. She was trained as a princess with the usual humanistic quest for comprehensive knowledge. Languages were her specialty, yet she delighted in all subjects. Music was her only recreation. She studied with the nuns of the Dominican convent in Barcelona and with hired tutors and learned to play the keyboards and "the lute," according to her early biographers who were French and thus, at the time, incapable of translating "vihuela" to a French equivalent. Nevertheless, Juliana must have played the vihuela, because it had become the royal standard. Juan Antonio attempted to ingratiate his daughter with the court, so vihuela performance would have been indispensable in her training.

38. The music of Apolonio (the little Apollo) had already been compared to that of Apollo and Orpheus before Petrarch and Boccaccio were born.

39. LOPE DE VEGA, Laurel de Apolo. Madrid: c.1630 (republished in Colección de las obras sueltas, assi en prosa como en verso, Tomo I. Madrid: Antonio de Sancha, 1776). 
In 1601 Juan Antonio Morell ran into legal problems that compelled him to flee Barcelona with Juliana. They went into exile in southern France, where he could extend his banking career and she could continue her training. Although she was soon called "the Doctoress" for all her learning, she stopped short of receiving the degree, which would have earned her the first female doctorate. ${ }^{40}$ This honor went to a Venetian musician of the next generation: Elena Lucrezia Cornaro Piscopia, who, at the University of Padua, completed the first Ph.D. that went to a woman. Instead, in 1609 Juliana chose to become a nun and joined the Dominican convent in Avignon, where she spent the rest of her days as prioress, professor, and author. Her manuscripts and posthumous publications all dealt with religious matters, although at the end of her career she returned to music by writing hymns.

More female musicians appeared in the works of Vicente Espinel, the writer recognized by Lope and Cervantes as a model guitarist at the turn of the century. Early in his career Espinel travelled continuously to perform his music and poetry in his own medium, the cantares de sala which he sang in the drawing rooms of the elite. Following in Lope's footsteps, he praised his friends in La casa de la memoria, a long poem he published in the Diversas rimas. ${ }^{41}$ Therein Espinel singled out the vihuelists Francisco Peraça and Francisco Guerrero, who both saw their portraits published in Francisco Pacheco's book of the illustrious men of Seville in 1599. Espinel made a similar allusion to female performance in which he implied that women were singing and accompanying themselves on the guitar. At the end of The House of Memory he praised four women and their music:

Doña Francisca de Guzmán se via Sereno el rostro en mouimientos graues

Tener suspensa aquella compañía

Con acentos dulcíssimos suaves...

En la divina mano el instrumento

Doña Ysabel Coello tiene y templa:

Oyelo el soberano coro atento,

Y la disposición, y arte contempla...

Llegó doña Ana de Suaço al coro

De Agustina de Torres, prenda cara,

$Y$ de boz y garganta abrió el tesoro,

Diestra discreta, y una y otra rara...
Lady Francisca de Guzmán could see The serene image in grave moves, Holding in suspense that company With the sweetest, suave moods...

In her divine hand, the instrument That Ysabel Coello had intoned, Played the choir accompaniment With disposition and art condoned...

Ana de Suaço came to the chorus Of Agustina de Torres - a lady dear, To show her treasured throat and voice, Agile and discreet, and yet so rare...

40. Theresa M. Lamy, "Juliana Morell: Child Prodigy, Religious Reformer, Spiritual Writer," Ph.D. diss., New York University, 1992 (copy from Ann Arbor: UMI), p. 26.

41. Vicente EsPINEL, La casa de la memoria in Diversas rimas. Madrid: Luis Sánchez, 1591 (ed. Dorothy Clotelle Clarke, New York: Hispanic Institute, 1956). 
Oyense de vna, y de otra parte acentos

Destos sujetos, y otros muchos juntos

Gallardas bozes, graues instrumentos

Galas pasajes, quiebros, contrapuntos.
Listen, here and there, to the accents

Of these subjects and other points:

Gallant voices, grave instruments,

Gala passages, trills, counterpoints.

Thus were they his acquaintances, singers who probably supplied their own instrumental accompaniments. Just as in Espinel's drawing-room songs, the guitar alone was sufficient background for their voices, and their music had consequences in their lives. Francisca de Guzmán became the Marquesa del Carpio. Lope confirmed the musicianship of two more in the Laurel de Apolo: Ana Zuazo and Isabel Coello. Coello was another prodigy and perhaps the best musician of all; she astonished the court of Valencia at the age of 17 with her learning and virtuosity on the harp, keyboards, and fretted instruments. ${ }^{42}$

The guitar was so widely accepted as a feminine instrument that it entered the Spanish convent. Although documentation of the secluded life remained scarce, evidence survived from the town of Avila. The Mother Superior there, at the Encarnación Convent named María Isabel Pinel, wrote twice concerning her musical charges to Miguel Gómez Camargo. In the year 1653 she reported on the fine guitar performances, in both the strummed and plucked styles, by one of the sisters:

[She plays the guitar very well, both rasgueado and punteado, and she accompanies with it whatever part is offered to her]. ${ }^{43}$

Besides the music of their personal devotions and worship, the sisters wrote and performed their own theatrical productions. The morality and miracle plays that thrived in the Spanish convent, sometimes required guitar accompaniment, as specified by María de San Alberto (1568-1640). She was born in Valladolid and, after joining the convent there, eventually served as the Carmelite Mother Superior. Madre María was a composer of poetry and music for the convent stage, and her stage directions incorporated vihuela music into her productions. Melodrama resulted when her actresses performed:

Based on a popular melody - the tonada - the tune was played on the vihuela, a forerunner of the guitar. Madre María, the author-director, states that the song should be played as background music throughout the piece. ${ }^{44}$

42. Gilbert ChaSe, The Music of Spain. Second revised ed. (New York: Dover, 1959), p. 55.

43. Miguel Querol, "Corresponsales de Miguel Gómez Camargo", Anuario Musical, XIV (1959), p. 170.

44. Electa AREnAl and Stacey Schlau, Untold Sisters: Hispanic Nuns in Their Own Works (Albuquerque: University of New Mexico Press, 1989), p. 149. 


\section{Queens of the Bourbon Dynasty}

The guitar became the absolute instrument of the Bourbon regime in Paris. Louis XIII and Louis XIV both played the guitar, a circumstance that came to be reinforced by their wives, the Habsburg princesses of Spain. When Louis XIV married Infanta Maria Teresa in 1660, he acceded to absolute power on the Continent, and so did the guitar. Once he had become its advocate, every courtier or courtesan had to try to play it, as they generally adopted French fashions, protocol, and speech at their own courts. Playing the guitar was no great concession to prevailing taste, but rather the least they could do. As they acquired some ability on the guitar, courtiers could stop short of studying ballet! Thus the guitar reigned with the Bourbons throughout the Baroque and Rococo eras, as portrayed in countless iconographical examples up to the French Revolution.

Simultaneously in Spain, the guitar continued to prosper until the end of the Habsburg dynasty. Lacking, however, are the names of the queens of the dynasty who employed guitarreros to maintain their instruments. The 17 th-century luthiers were stringing, repairing, or even building the instruments belonging to the royal family or their attendants:

[It is known that the following were named master guitarreros of the queen: in 1638, Gabriel Puche, resident of Toledo; in 1681, Marcos Jiménez, who also made a harp for her majesty; in 1704, Antonio de Murcia; in 1709, Juan de Campos]. ${ }^{45}$

Santiago de Murcia, Spain's foremost baroque guitarist, emerged from this line of musicians in courtly service. He was born in Madrid about 1682, as the probable son of two lines of musicians who had served the court: Gabriel de Murcia, who was in the service of Carlos II in 1690, and Juliana de León, the daughter of Francisco de León, who was the Queen's guitarrero, according to documents left in the palace. ${ }^{46}$ Francisco de León maintained the Queen's instruments and served as national advisor to the guild of guitarreros. The Queen was then Carlos II's consort, the musical Marie-Louise of Orleans (1662-1689), daughter of Philip, Duke of Orleans and Henrietta Stuart. Upon the death of Francisco in 1679, Juliana served in her father's post until 1682, when it was filled from the ranks of the guild. ${ }^{47}$ Thus Marie-Louise employed at least three guitarreros in succession.

The Queen's family background appears in Table 3, a genealogical chart to show the extent of the guitar's impact amidst some of the Baroque royalty. The caption, "Guitarre Roya(1920), p. 85

45. Ricardo de Aguirre, "Noticias para la historia de la guitarra," Revista de Archivos, Bibliotecas y Museos, XXIV

46. Elena MACHAdo Lowenfeld, "Santiago de Murcia's Thorough-bass Treatise for the Baroque Guitar (1714): Introduction, Translation and Commentary," Master's thesis, City University of New York, 1975 (copy from Ann Arbor: UMI), p. 5.

47. Craig H. Russell, Santiago de Murcia's "Códice Saldívar No. 4", a Treasury of Secular Guitar Music from Baroque Mexico, 2 vols. (Urbana and Chicago: University of Illinois Press, 1995), vol. I, p. 126. 
lle" originated with Francesco Corbetta's guitar book written for Charles II of England and published in 1671. Unfortunately space here does not permit an account of the guitar's pervasive impact on the Stuart dynasty. ${ }^{48}$

By turn of the century, the house of Habsburg had run its course in Madrid, and a change in the monarchy would serve to establish a new generation of guitarists at court. Carlos II, lacking a male heir to the throne, bequeathed Spain to distant relatives in France. The Bourbons had already assumed power at Paris when Anthony de Bourbon's son, Henry IV, came to the throne late in the 16th century. The Bourbons assumed power at Madrid in 1700, and though they had come from afar, they brought even more reinforcement to the guitar's prestige. Philippe, Duke of Anjou, who was the Bourbon descendant of Louis "Monseigneur le Dauphin" and Marie-Anne of Bavaria and grandson of Louis XIV, accepted the throne as Felipe V. Madrid's new monarch must have at least kept a passive interest in the guitar, inasmuch as it had been the favorite of his forebears on all sides of the family; his consort, at any rate, took an active interest in it. Queen Marie-Louise-Gabrielle of Savoy (1688-1714) helped to launch the new dynasty, and the guitar ascended apace. The young Queen was herself a guitarist, for according to a letter to her grandmother in the summer of 1705 , the study of instrumental music had become one of her pastimes:

[I assure you that...although I certainly have no diversion with which to pass the time... the days do not seem too long. As you know, I never have reading nor work to do, though it would be an amusement. On the days of the postal courier I write. I play the harpsichord, I am learning to play the guitar, and I am also studying music]. ${ }^{49}$

By playing the guitar Maria Luisa Gabriela (as she was known, in full, to distinguish her from predecessors and followers) kept the instrument's prestige intact, for the new Queen made the guitar a continuing performance medium for women of the new dynasty. She summoned the Murcias to her service: Antonio to maintain her instruments and Santiago to perform in her personal chambers. She took lessons with Santiago, as suggested in the title of his book on guitar accompaniment, which he published in 1714 under the patronage of Francisca de Chavarri. His guitar manuscripts imply, furthermore, that it was he who introduced the fandango and other risque dances (which replaced the old guitar forms of the chacona, zarabanda, and folía) with sufficient polish that the new forms gained courtly acceptance. Santiago de Murcia must have wished to praise the Queen with the guitar pieces in his book on accompanying entitled "La borbón" and "La saboyana, buree," for she was not Spanish.

48. During the Restoration of the 1660 s, Charles II established the guitar as the royal preference over his mother's lute. The guitar thereafter became the favorite instrument of the English princesses, queens, and upper classes. See R. PINNELL, Francesco Corbetta and the Baroque Guitar... Studies in Musicology No. 25 (Ann Arbor: UMI Research Press, 1980), vol. I, p. $131 \mathrm{ff}$.

49. Lucien PEREY [pseud. for Clara-Adèle Herpin], Une Reine de douze ans: Marie-Louise-Gabrielle de Savoie, Reine d'Espagne (Paris: Calmann-Lévy, 1905), p. 371. 


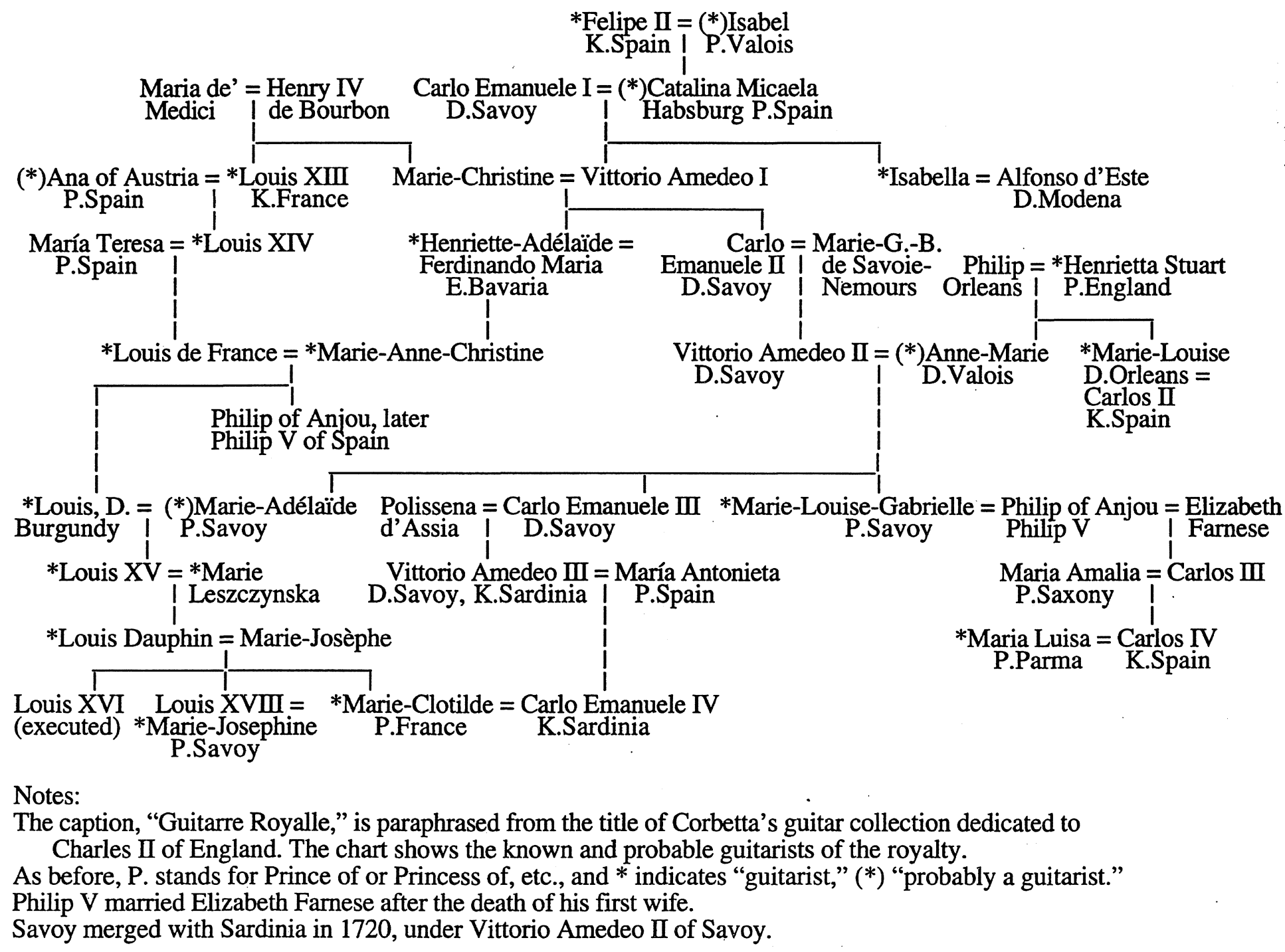

Notes:

The caption, "Guitarre Royalle," is paraphrased from the title of Corbetta's guitar collection dedicated to

Charles II of England. The chart shows the known and probable guitarists of the royalty.

As before, P. stands for Prince of or Princess of, etc., and * indicates "guitarist," (*) "probably a guitarist."

Philip V married Elizabeth Farnese after the death of his first wife.

Savoy merged with Sardinia in 1720, under Vittorio Amedeo II of Savoy. 
Queen Marie-Louise-Gabrielle hailed from Savoy, where the princesses were famous guitarists. ${ }^{50}$ Mounting evidence points to some princess before 1600 who must have established this

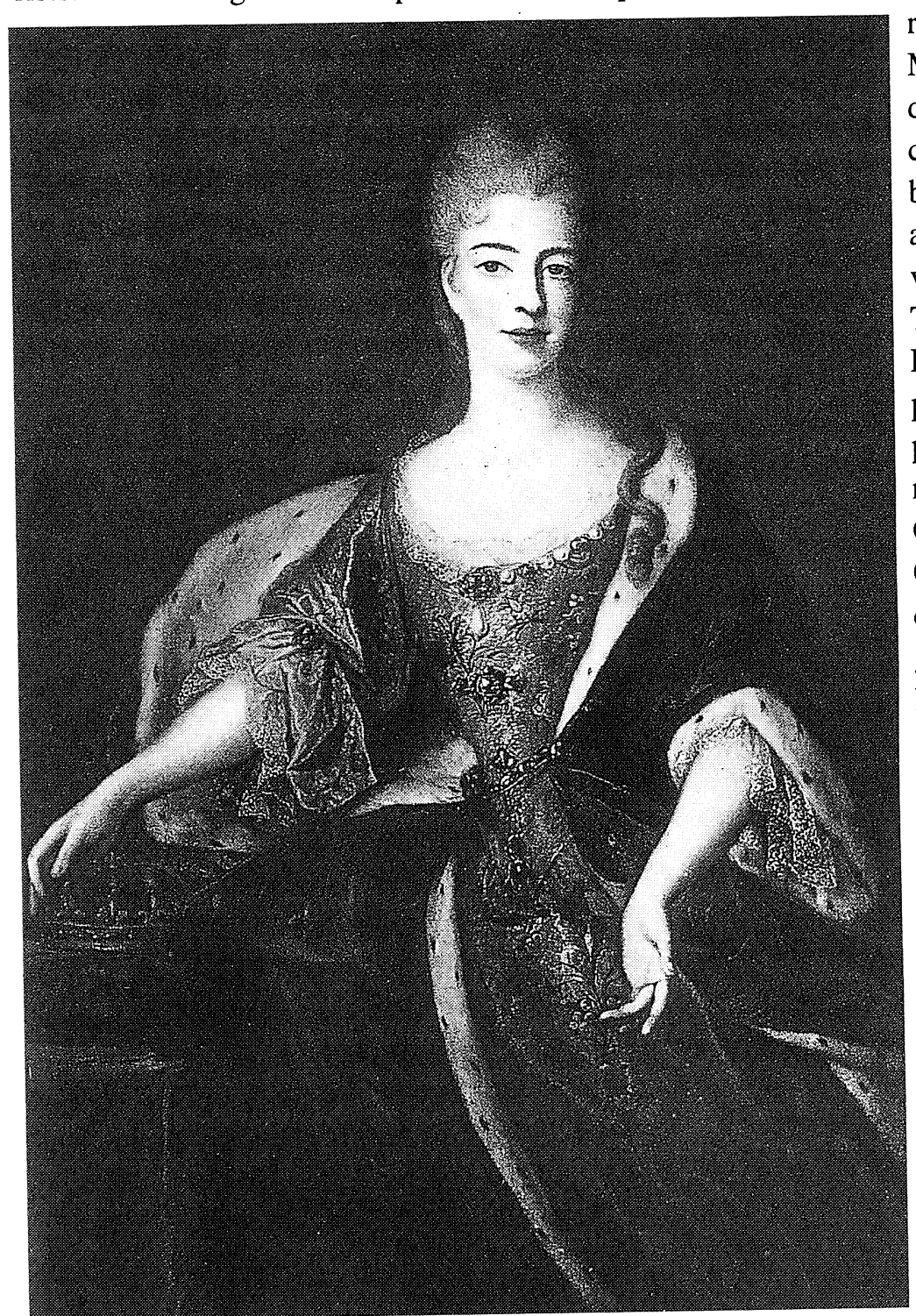
renown, someone like Catalina Micaela (d.1597). Felipe II's daughter by Isabel de Valois, Princess Catalina Micaela had probably gone to her appointment as a vihuelist like her father. She travelled to the riviera capital at Turin and married Duke Carlo Emanuele I (see Table 3). Her posterity thereafter contained princess guitarists in every generation leading to Marie-LouiseGabrielle. Moreover, the new Queen's grandmother was Princess Henrietta Stuart, who was a guitarist à la mode at the time of her marriage to Philip, Duke of Orléans. Henrietta reinforced the musical tradition at Savoy when her daughter Anne-Marie married Vittorio Amedeo II, and the two became Marie-Louise-Gabrielle's parents. Both Isabella and Henrietta-Adélaïde of Savoy $^{51}$ as well as Marie-Anne of Bavaria had been accomplished guitarists before her. Thus Queen MarieLouise-Gabrielle descended from the long line of Savoyards, Bourbons, and Stuarts who had already taken to the guitarre royalle.

Marie-Louise-Gabrielle of Savoy, Queen of Spain

[anonymous portrait from Perey's biography]

50. Savoy, like the Holy Land, was a diminutive but desirable strip linking aggressive superpowers of the Mediterranean. Savoy's armies were small, a fact which pressed its princesses all the more for making political liaisons by marriage. Finally by around 1800 war-torn Savoy lost its distinction: the riviera came to be subdivided between France, Italy, and smaller principalities. Its extensive royal lineage has been traced in the "Savoia" article of the Enciclopedia italiana di scienze, lettere ed arti (Rome: G. Tracciani, 1949), table 9.

telli Boca, 1926), p. 97. 
The guitar's 18th-century visibility was enhanced by yet another royal patroness in Madrid. Queen María Luisa de Parma (1751-1819) shared her interest in the guitar with Manuel Godoy at the end of the century. Godoy came up through the ranks quickly because of his affability, good looks, and many talents. He had mastered the swashbuckling skills of marksman and horseman, but once he made it into the tertulias of the court, his abilities as singer and guitarist helped to endear him to high society. He became the chief minister during the reign of Charles IV and his consort María Luisa, as well as the Queen's favorite. The Queen studied under Padre Basilio, partly because the guitar was again in vogue:

The last eighteenth-century Queen was taught guitar playing by a very learned priest, Padre Basilio, who made the Spanish guitar very fashionable at the Spanish court. Both the Queen, another Maria Luisa, and her favorite, Godoy, the Prince of Peace, were fascinated by the guitar. ${ }^{52}$

The Queen studied with Padre Basilio at Escorial, where he had many students. ${ }^{53}$ Thus the guitar soared again in the hands of yet another queen.

\section{Conclusions}

The guitarra española's importance was concisely summarized in its own day by the French historians who had witnessed some of its impact:

[There are but few nations that find more passion for music than the Spaniards, since there is no youth who does not know how to play a little on the guitar or the harp. These are the instruments that serenaders use to entertain their mistresses when passing their nights in Madrid as well as in the other towns of the realm. One sees an infinity of lovers who run in the streets with their guitars and their dim lanterns. There is no artisan who, after his work, does not take up his guitar to find diversion in public places. A laborer never works without having his guitar or his harp hung behind his back. There are few Spanish men and women of distinction who do not know how to accompany their voice on these instruments. $]^{54}$

52. Mary Neal Hamilton, Music in Eighteenth Century Spain. Urbana: University of Illinois, 1937 (reprint, New York: Da Capo, 1971 ), p. 148. 1974), p. 82 .

53. Harvey TuRnbull, The Guitar from the Renaissance to the Present Day (New York: Charles Scribner's Sons,

54. Jacques BonNet, ed., Histoire de la musique et de ses effets depuis son origine jusqu'à présent by Pierre Bourdelot and Pierre Bonnet-Bourdelot. Paris: Cochart, Ganeau \& Quillau, 1715 (facs. reprint, Geneva: Slatkine, 1969), p. 377f. 
The world of the Spanish guitar in its place of origin, was therefore but a microcosm of its later status in Europe. The guitar was the instrument of the people, including the youth of the streets, and of course, the Gypsies, who had preserved the fandango in the popular repertoire. ${ }^{55}$ The guitar was part of many forms of light entertainment such as serenades, masquerades, and popular and courtly dances. Only the theatre was exceptional. The guitar certainly occupied the limelight of some theatrical productions elsewhere on the Continent, but never with the frequency established by Cervantes and Lope de Vega. The guitar was even part of the lifestyle of the convent and the court, appearing in the intimate chambers of nuns, femmes savantes, and princesses as the era's most democratic instrument. Female guitarists were mostly amateurs, though they must not be prejudged for this fact, and they always preferred performance over composition. Social norms generally compelled them to stay at home, but this did not hinder their inclination to perform. Their musical abilities contributed to the success of their social encounters, which provided plenty of additional incentive to practice besides the artistic muse. They excelled in their own way, but excel they did.

Women determined the guitar's success at the key junctures of its early history: amidst the juglaresas and royalty of the Middle Ages, amidst the royalty, virtuosi, and composers of the Siglo de Oro, in the guitar's expatriation to Spanish-speaking Naples (1550-1600) and thence to the other city-states. The Spanish guitar's international impact began with the Neapolitan virtuosas: the rise of the solo singer with a secular repertoire, the revival of the romance ballad and its homophonic texture, a figured bass with improvised chords, etc. - some of the salient innovations of Baroque music. Popular dances replaced the romance beyond Naples (wherever Spanish was not the lingua franca), which paved the way for guitar music to enter the international dance suite to represent Spain. In 1660 the guitar became the absolute instrument simultaneously under the Savoyards, the Stuarts, and the Bourbons, who extended their genetic and guitaristic legacy into Spain. Not until the French and Industrial Revolutions did the guitar movement come to an end. The archaic instruments fell into oblivion as they came to be replaced by the modern alternatives: the viol by the violin, the harpsichord and clavichord by the piano, the baroque guitar and lute by the classical guitar, etc. Here too women kept the controlling interest. It was neither Mozart nor Beethoven who established the pianoforte in the salon at the end of the 18th century, but rather the bourgeoisie's better half. After 1800 didn't every woman's salon have to have a piano?

Until now the role of women in the guitar's fame and fortune has been underestimated. It was an integral role in Spain. The Spanish princesses and queens, in particular, were significant

55. See my chapter on the fandango in The Rioplatense Guitar, Volume I: The Early Guitar and Its Context in Argentina and Uruguay (Westport: The Bold Strummer, Ltd.), 1993. 
as they intervened in the historical eras between 1300 and 1800 . They lent their prestige to the instrument, which made it acceptable everywhere. The guitar thus became the most popular instrument in the world, and the world would never have been the same without the ubiquitous guitar. 